\title{
Growing Conflicts between Intellectual Property Rights and Health
}

\section{Tania Voon*}

Melbourne Law School, University of Melbourne, Victoria 3010, Australia

The relationship between intellectual property and health is coming increasingly to the fore in a range of international contexts. In connection with the World Health Organization ('WHO'), for example, tensions have arisen in crafting an appropriate response to so-called 'counterfeit' medicines. In November 2012, the Member State Mechanism established by the World Health Assembly (the decisionmaking body of the WHO) to promote collaboration on counterfeit and related medical products (that is, 'substandard/spurious/falselylabelled/falsified/counterfeit' medical products) held its first session, revealing continued difficulties in navigating the distinct public health and intellectual property perspectives of such products [1]. Also in November 2012, the Conference of the Parties to the WHO Framework Convention on Tobacco Control ('WHO FCTC') adopted the Protocol to Eliminate Illicit Trade in Tobacco Products. The conclusion of the Protocol brings significant aspects of customs and law enforcement uncomfortably into a public health treaty [2,3], although the word 'counterfeit' was removed in the Protocol's final negotiating session due to serious concerns about a health protocol protecting intellectual property of the tobacco industry [4].

The battle between tobacco trademarks and public health regulation has taken centre stage in a series of domestic and international disputes over Australia's world-first legislation to standardise tobacco product packaging, which was fully implemented on 1 December 2012. The Tobacco Plain Packaging Act 2011 (Cth) and related regulatory measures increase the size of health warnings, preclude the use of commercial graphics and logos, and specify the colour of tobacco product packages ('drab dark brown') and the font style and size of brand and variant names. Fearful of the global precedent that this legislation may set, the tobacco industry has launched legal challenges in every possible forum. The government has vowed to defend its legislation against each of these challenges, in view of its objectives of improving public health and giving effect to certain of Australia's obligations as a party to the WHO FCTC.

Domestically, several tobacco companies challenged the legislation on constitutional grounds within the High Court of Australia (Australia's highest court), alleging that the government had acquired property (particularly trademarks) other than on just terms, contrary to section 51(xxxi) of Australia's Constitution. The Court's orders, finding in favour of the government and requiring the plaintiffs to pay the defendant's costs, were published in August 2012. In October 2012, the Court delivered its reasons. By a majority of six to one, the Court found that the legislation did not effect an acquisition of property, essentially because neither the government nor anyone else obtained a proprietary benefit from the operation of the legislation; the legislation's contribution to the government's health objectives does not amount to a benefit of a proprietary nature [5].

Two international disputes on Australia's plain packaging legislation continue. Pursuant to the Australia - Hong Kong Bilateral Investment Treaty, Philip Morris Asia Limited ('PMA') has launched an investment arbitration against Australia, alleging, among other things, unlawful expropriation of its intellectual property rights including trademarks. Australia has made a number of jurisdictional objections to this claim, including in connection with the fact that PMA's investment in Australia was made only after the government had announced its plain packaging scheme. That temporal aspect of the dispute is also likely to affect substantive questions in dispute, such as PMA's legitimate expectations about the regulatory environment at the time of making its investment [6]. The dispute is likely to proceed quite slowly, as confirmed by initial procedural orders recently made public.

Finally, within the WTO, and with the support of tobacco interests, three countries have requested the establishment of a panel to hear a dispute against Australia about plain tobacco packaging. Ukraine, Honduras and the Dominican Republic each claim violations of several WTO agreements, including the Agreement on Trade-Related Aspects of Intellectual Property Rights ('TRIPS'). Specifically, the complainants allege violation of TRIPS provisions concerning the registration and use of trademarks, and discrimination in the treatment of nationals from different countries with respect to intellectual property protection. Given the importance of the measure to Australia and to the tobacco industry, we can expect a vigorous proceeding, including an appeal. Although some of the questions the dispute raises are novel in the context of WTO dispute settlement, the government has reason to be confident of the outcome [7].

This series of challenges to plain tobacco packaging raises fundamental issues about the nature of intellectual property rights, the balancing required at the sovereign level between intellectual property rights and other interests, and the ability of international trade and investment treaties to accommodate public policies such as the protection of health. Underlying assumptions and principles of intellectual property protection may be tested, and the results may have implications for future disputes in a range of areas. The concurrence of disputes also provides opportunities for the reasoning of each tribunal to be examined in the others, increasing the possibility of consistent decision-making. The outcomes on all fronts may not be known for several years; in the meantime, these disputes deserve careful attention.

\section{References}

1. Burci GL (2013) Public Health and "Counterfeit" Medicines: The Role of the World Health Organization. Am Soc Int Law 17.

2. Liberman J (2012) Combating Counterfeit Medicines and Illicit Trade in Tobacco Products: Minefields in Global Health Governance. J Law Med Ethics 40: 326-347.

3. Liberman J (2012) The New WHO FCTC Protocol to Eliminate Illicit Trade in Tobacco Products - Challenges Ahead. Am Soc Int Law 16.

4. New W (2012) "Counterfeit" Dropped From New WHO Protocol on Illicit Tobacco Trade. Intellectual Property Watch.

*Corresponding author: Tania Voon, Professor, Melbourne Law School, University of Melbourne Victoria 3010 Australia, Tel: +61 38344 1119; E-mail: tania.voon@unimelb.edu.au

Received January 15, 2013; Accepted January 17, 2013; Published January 19 2013

Citation: Voon T (2013) Growing Conflicts between Intellectual Property Rights and Health. Intel Prop Rights 1: e101. doi:10.4172/2375-4516.1000e101

Copyright: @ 2013 Voon T. This is an open-access article distributed under the terms of the Creative Commons Attribution License, which permits unrestricted use, distribution, and reproduction in any medium, provided the original author and source are credited. 
Page 2 of 2

5. Voon T (2013) Acquisition of Intellectual Property Rights: Australia's Plain Tobacco Packaging Dispute. European Intellectual Property Review.

6. Voon T, Mitchell A (2011) Time to Quit? Assessing International Investment
Claims Against Plain Tobacco Packaging in Australia. J Int Economic Law 14 515-552.

7. Voon T, Mitchell A (2012) Implications of WTO Law for Plain Packaging of Tobacco Products. SSRN 109-136. 